\title{
Self-assembling functional programmable protein array for studying protein-protein interactions in malaria parasites
}

\author{
Gabriela Arévalo-Pinzón 1,2, María González-González 3,4, Carlos Fernando Suárez 1,5, Hernando Curtidor 1,6, \\ Javier Carabias-Sánchez ${ }^{3}$, Antonio Muro ${ }^{7}$, Joshua LaBaer ${ }^{8}$, Manuel Alfonso Patarroyo ${ }^{1,6}$ and Manuel Fuentes ${ }^{3,4^{*}}$
}

\begin{abstract}
Background: Plasmodium vivax is the most widespread malarial species, causing significant morbidity worldwide. Knowledge is limited regarding the molecular mechanism of invasion due to the lack of a continuous in vitro culture system for these species. Since protein-protein and host-cell interactions play an essential role in the microorganism's invasion and replication, elucidating protein function during invasion is critical when developing more effective control methods. Nucleic acid programmable protein array (NAPPA) has thus become a suitable technology for studying protein-protein and host-protein interactions since producing proteins through the in vitro transcription/translation (IVTT) method overcomes most of the drawbacks encountered to date, such as heterologous protein production, stability and purification.
\end{abstract}

Results: Twenty P. vivax proteins on merozoite surface or in secretory organelles were selected and successfully cloned using gateway technology. Most constructs were displayed in the array expressed in situ, using the IVTT method. The PV12 protein was used as bait for evaluating array functionality and co-expressed with P. vivax cDNA display in the array. It was found that $P \vee 12$ interacted with $P \vee 41$ (as previously described), as well as $P V M S P 1_{42 \mathrm{kDa}}$ PVRBP1a, PVMSP8 and PVRAP1.

Conclusions: NAPPA is a high-performance technique enabling co-expression of bait and query in situ, thereby enabling interactions to be analysed rapidly and reproducibly. It offers a fresh alternative for studying protein-protein and ligand-receptor interactions regarding a parasite which is difficult to cultivate (i.e. P. vivax).

Keywords: Plasmodium vivax, Malaria, NAPPA array, IVTT protein expression, Protein-protein interaction

\section{Background}

Malaria is one of the most important tropical diseases transmitted by vectors worldwide; Plasmodium vivax represents one of the most widely distributed species (affecting $\sim 13.8$ million people worldwide per year). Despite this, the apparently slow progress of infection and low parasitaemia levels in humans compared to those reported in Plasmodium falciparum have erroneously led to $P$. vivax infection being classified as benign. Added to this, the experimental challenges involved in culturing

\footnotetext{
*Correspondence: mfuentes@usal.es

3 Proteomics Unit, Cancer Research Centre (IBMCC/CSIC/USAL/IBSAL),

37007 Salamanca, Spain

Full list of author information is available at the end of the article
}

this parasite greatly hinder accumulating the biological, cellular and molecular knowledge necessary for developing effective control methods against $P$. vivax. Although $P$. vivax invasion is thought to be similar to that of $P$. falciparum, some biological differences condition disease severity and hamper its biological study $[1,2]$.

Plasmodium parasites have a diverse ligand repertoire [3] and adapt to differing conditions [4, 5]; however, the scenario is much more complex. Evidence has grown regarding macromolecular complex formation between ligands [6-8] and host surface molecule multimeric assemblies which could favour and increase the strength of any receptor-ligand interaction [6-13]. However, little is known about macromolecular complexes 
and host-pathogen interactions concerning $P$. vivax [14]. Some proteins' functions have been speculated about to date on the basis of their counterparts in other species [15], mainly due to this species preferential invasion of young $\mathrm{RBC}$, meaning that no continuous in vitro culture is available for real-time evaluation of protein interactions during invasion [2]. Moreover, a preliminary characterization of such multimeric complexes has also been hampered by the technical challenges when expressing recombinant proteins in an active, soluble and immunogenic form in cell-based expression systems (CBES), particularly for the extracellular ones which might participate during merozoite invasion of target cells. Several factors negatively affecting obtaining Plasmodium proteins in CBES have been described, such as the existence of long stretches of repeated amino acid sequences, the high isoelectric point, and the presence of signal peptide, GPI anchor or transmembrane regions $[16,17]$. In addition, the high AT-content results in low codon usage compatibility in heterologous expression systems, such as Escherichia coli [18]. Other factors like the presence of disulfide bridges encompassing important structural domains represent a challenge when obtaining properly folded proteins. In contrast to CBES, cell-free expression systems (CFES) based on eukaryotic or prokaryotic cell extracts (i.e. E. coli, wheat germ extract (WGE), rabbit reticulocyte lysate (RRL), HeLa, etc.) [19-22] offer a viable alternative for expressing soluble Plasmodium proteins displaying the proper conformation [23-26]. Moreover, the CFES substantial time-savings ( $2 \mathrm{~h}$ vs. $24-48 \mathrm{~h}$ for protein expression), have the ability to adapt to highthroughput formats, increased tolerance to additives and less sensitivity to toxic or proteolytic proteins when compared to CBES [27]. In previous study, WGE was used for expressing 89 soluble $P$. vivax proteins and analysing the immunoproteome, four potential antigens (including Pv24) were identified [28]. Other study, comparing the expression of five $P$. vivax vaccine candidate antigens between extracts from prokaryotic ( $E$. coli) and WGE cells, has shown that despite both systems allow producing soluble proteins that are easily detectable, proteins produced in the eukaryotic system were recognized by a greater number of sera from $P$. vivax-infected patients than identical proteins produced in E. coli extracts [29]. Together, these data showed that CFES, particularly the eukaryotic ones, represent a good choice for studying $P$. vivax proteins.

Interestingly, CFES have been successfully coupled to both solid and suspension arrays, mainly being used for to identify novel blood-stage malaria vaccine candidates through antibody reactivity from adults who lived in a malaria endemic area [30-32]. In this approach,
CFES-expressed polypeptides are then printed on the array. This methodology, however, has some drawbacks such as the requirement of maintaining cold-chain after protein expression to avoid losing protein function and that printing thousands of recombinant proteins on a chip is a laborious task, reduces reproducibility and increases costs.

Several arrays that allow protein expression in situ have been developed during the last few years to overcome the above-mentioned problems, such as DNAarrays to protein-arrays (DAPA), Protein in situ arrays (PISA) and Nucleic Acids Programmable Protein Arrays (NAPPA). NAPPA produces protein microarrays using CFPS (mainly RRL) to transcribe and translate cDNA-encoded bait proteins directly onto glass slides $[29,33]$. De novo synthesized proteins are directly captured by anti-tag antibodies co-spotted with specific cDNA. A target/bait in vitro transcription/translation (IVTT) expressed protein is thus captured onto the surface ready for functional assays; this approach has been successfully used in applications such as vaccine development and evaluating autoimmune responses and protein-protein interactions [34-36]. A query protein is simultaneously IVTT co-expressed with target/ bait proteins in protein interaction assays; however, this approach requires a different $\mathrm{C}$-terminal tag. Such approach has been successfully used in several applications, i.e. determining Legionella pneumophila effector (SidM and LidA) interaction network with 10,000 unique human proteins [36] and evaluating anti-serum profiles and protein interactions in a cDNA expression library from Ornithodoros moubata salivary glands [37].

The difficulty of maintaining a continuous $P$. vivax culture hampers evaluating protein-protein interactions when using functional approaches such as knockouts (total, conditional with or without complementation) [4, 38], knockdowns or inhibition assays [39]. Alternatives are needed and NAPPA technology thus stands out as a very good choice for studying $P$. vivax host-pathogen and protein-protein interactions. The present study involved designing and developing a NAPPA array constructed by non-contact printing of 20 P. vivax key genes encoding proteins which might be involved in Mrz invasion of reticulocytes.

Each gene was sub-cloned in a vector compatible with the IVTT expression system encoding a C-terminal tag. Such array has been optimized and fully-characterized to study in situ protein interactions enabling new insights regarding the macromolecular complexes involved in $P$. vivax protein-protein interactions. 


\section{Methods}

\section{Primer design}

Primers containing a partial $a t t B$ recombination sequence flanking a gene-specific sequence were used for amplifying genes of interest from $P$. vivax cDNA or gDNA (Table S1). For example, the forward primer 5'-AAAGCAGGCT TCGAAGGAGATAGA ACCATG GAAACAGAAAGTTATAAGCAGC-3', having the partial $a t t B$ sequence (in bold) included a gene-specific portion (underlined) and Shine Dalgarno and Kozak consensus sequences to enable protein expression (italics); the reverse primer $5^{\prime}$-AGAAAGCTGGGTCTCC TGTTGTTCCAGGCTGTACC-3' included a partial $a t t B$ sequence and the gene-specific portion. The stop codon was removed to enable the PCR product to be fused in frame with a C-terminal GST tag. A set of universal primers containing complete attB1 (GGGGACAAG TTTGTACAAAAAAGCAGGCTTCGAAGGAGAT) and $a t t B 2$ (GGGGACCACTTTGTACA $\underline{\text { AGAAAGCTG }}$ GGTCTCC) sequences were also synthesized. Regions overlapping the partial $a t t B$ sequence from gene-specific primers are underlined.

To fuse $P v 12$ in frame with an N-terminal Halo tag, gene specific primers (underlined) were designed with the complete $a t t B$ recombination sequence (in bold) (forward 5'-GGGGACAAGTTTGTACAAAAAAGC AGGCTCCACGTGCGATTTTAATG-3'; reverse 5'-GGGGACCAC TT TGTACAAGAA AGCTGGGT CCTAGCCCTGCAGAACATTCGC-3'). The initiation (ATG) codon was deleted in each forward primer and the stop codon was maintained in all reverse primers (in italics).

The region encoding the ectodomain was selected for each gene, excluding signal peptide, transmembrane domain and glycosylphosphatidylinositol (GPI) anchor sequences (when present). For some proteins (such as PvMSP1, PvRBP1a, PvDBP and PvRON2), several fragments based on functional or previously studied regions were amplified (Table 1).

\section{Cloning and subcloning}

The first round of PCR involved $50 \mu \mathrm{L}$ containing 25 $\mu \mathrm{L} 2 \times$ KAPA HiFi Ready Mix, $3.0 \mu \mathrm{L}$ of each specific primer $(5 \mu \mathrm{M}$ concentration partial attB recombination sequence), $15 \mu \mathrm{L}$ nuclease-free water and $P$. vivax cDNA or gDNA as template. PCR conditions for each gene involved an initial denaturing step at $95{ }^{\circ} \mathrm{C}$ for $3 \mathrm{~min}$, followed by 35 cycles consisting of denaturing at $98{ }^{\circ} \mathrm{C}$ for $20 \mathrm{~s}$, annealing at $58-60{ }^{\circ} \mathrm{C}$ for $30 \mathrm{~s}$ and an extension step at $72{ }^{\circ} \mathrm{C}$ for $1-2 \mathrm{~min}$. A final extension cycle lasted $5 \mathrm{~min}$ at $72{ }^{\circ} \mathrm{C}$. The product obtained from each gene was purified by Wizard SV Gel and PCR Clean-Up System (Promega), according to the manufacturer's specifications.
The second round of PCR involved $50 \mu \mathrm{L}$ reaction including a set of universal primers (5 $\mathrm{M}$ concentration), 25 $\mu \mathrm{L} 2 \times$ KAPA HiFi Ready Mix, $15 \mu \mathrm{L}$ nuclease-free water and the purified product obtained in the first PCR to introduce the remainder of the $a t t B$ sequence needed for recombination using the Gateway system (Invitrogen) [40]. The product obtained from each gene was purified and then used for BP recombination.

Obtaining the pDONR constructs involved transferring $100 \mathrm{fmol}$ of each purified insert into the attP sequencecontaining pDONR221 entry vector $(150 \mathrm{ng} / \mu \mathrm{L})$ in $2 \mu \mathrm{L}$ $\mathrm{BP}$ clonase (Invitrogen). The reaction was incubated for $4 \mathrm{~h}$ at $25^{\circ} \mathrm{C}$ and then used to transform One Shot TOP10 chemically competent $E$. coli (Invitrogen). The cells were plated onto LB agar-kanamycin and colonies were screened by PCR to identify positive clones. Five positive clones were sequenced with M13 forward and reverse primers to confirm the presence of the $P$. vivax attL genespecific sequence.

LR reactions for transferring the pDONR221-containing attL sequence into $a t t R$-containing pANT7-cGST or PJFT7-nHalo involved $20 \mu \mathrm{L}$ LR enzyme (Invitrogen) 1:1 ratio (donor:destination vector, each at $150 \mathrm{ng} / \mu \mathrm{L}$ ) for $1-4 \mathrm{~h}$ at $25^{\circ} \mathrm{C}$. Transfer reactions were used to transform the DH5 $\alpha$ competent $E$. coli strain (Invitrogen) which was then plated onto LB agar-ampicillin.

\section{Plasmid sequencing}

The University of Salamanca's (CSIC) Cancer Research Centre (Spain) sequenced all pANT7-cGST inserts in both strands using primers flanking the recombination regions (forward: 5'-TAATACGACTCACTATAG -3'; reverse: 5'-CCGCAAGCTTGTCATCAACCACTT $\left.-3^{\prime}\right)$. Ten plasmids from the expression library were randomly selected to assess insert presence by restriction with BsrGI (New England) and to discard plasmid degradation.

The $p v 12$ gene cloned into pJFT7-nHalo was sequenced in both strands by using primers flanking the recombination regions (forward: 5'-CCCATTGTATGGGATCTG ATC-3'; reverse: 5'-TGTTTCGCCATTTATCACCTTC$\left.3^{\prime}\right)$ at the sequencing service of the Cancer Research Centre (University of Salamanca-CSIC, Spain).

\section{Sample preparation, substrate functionalization and array printing}

Sample preparation involved seeding $3 \mu \mathrm{g}$ of each purified plasmid DNA in a 384-well microtitre plate and then incubating overnight at $40{ }^{\circ} \mathrm{C}$ to allow the DNA to dry; 12 $\mu \mathrm{L}$ master mix solution (containing $33.3 \mathrm{mg} / \mathrm{mL}$ bovine serum albumin (BSA), $2.5 \mathrm{mg} / \mathrm{mL}$ rabbit polyclonal antiGST antibody and $2 \mathrm{mM}$ Bis-(sulfosuccinimidyl) suberate (BS3)) was added to each precipitated plasmid DNA 
Table $1 P$. vivax proteins selected for NAPPA array

\begin{tabular}{|c|c|c|c|c|c|c|}
\hline Annotation & Pv gene ID & Time transcription $^{a}$ & Localization & Proteome data $^{c}$ & Fragments & Regions expressed \\
\hline \multicolumn{7}{|l|}{ Target $P$. vivax proteins } \\
\hline $\begin{array}{l}\text { Merozoite surface } \\
\text { protein } 1 \text { (PVMSP1) }\end{array}$ & PVX_099980 & TP7 & Merozoite surface & $x$ & 2 & ${ }^{1350} \mathrm{D}-\mathrm{F}^{1723 ;} ;{ }^{761} \mathrm{G}-\mathrm{E}^{1349}$ \\
\hline $\begin{array}{l}\text { Merozoite surface } \\
\text { protein } 4 \text { (PVMSP4) }\end{array}$ & PVX_003775 & TP7 & & & 1 & ${ }^{30} I-S^{248}$ \\
\hline $\begin{array}{l}\text { Merozoite surface } \\
\text { protein } 8 \text { (PVMSP8) }\end{array}$ & PVX_097625 & TP2 & & $x$ & 1 & ${ }^{24} G-Y^{462}$ \\
\hline $\begin{array}{l}\text { Merozoite surface pro- } \\
\text { tein } 10 \text { (PvMSP10) }\end{array}$ & PVX_114145 & TP7 & & & 1 & ${ }^{30} L-A^{459}$ \\
\hline $\begin{array}{l}\text { 6-Cysteine protein } 41 \\
\text { (Pv41) }\end{array}$ & PVX_000995 & TP7 & & $x$ & 1 & ${ }^{19} \mathrm{~A}-\mathrm{Q}^{383}$ \\
\hline $\begin{array}{l}\text { 6-Cysteine protein } 12 \\
(P \vee 12)\end{array}$ & PVX_113775 & TP7 & & $x$ & 1 & ${ }^{27} \mathrm{~T}-\mathrm{G}^{336}$ \\
\hline $\begin{array}{l}\text { Asparagine rich protein } \\
\text { (PvARP) }\end{array}$ & PVX_090210 & TP7 & & $x$ & 1 & ${ }^{16} C-V^{284}$ \\
\hline $\begin{array}{l}\text { Thrombospondin- } \\
\text { related protein } \\
\text { (PVTRAMP) }\end{array}$ & PVX_123575 & TP8 & Apical/merozoite surface & & 1 & ${ }^{24} \mathrm{~K}-\mathrm{I}^{300}$ \\
\hline $\begin{array}{l}\text { Merozoite surface } \\
\text { protein } 5 \text { (PVMSP5) }\end{array}$ & PVX_003770 & TP8 & Micronemes/apical & $x$ & 1 & ${ }^{22} \mathrm{R}-1^{362}$ \\
\hline $\begin{array}{l}\text { Apical merozoite anti- } \\
\text { gen } 1 \text { (PVAMA1) }\end{array}$ & PVX_092275 & TP8 & & $x$ & 2 & ${ }^{43} \mathrm{P}-\mathrm{E}^{343} ;{ }^{43} \mathrm{P}-\mathrm{L} 487$ \\
\hline $\begin{array}{l}\text { Duffy binding protein } 1 \\
\text { (DBP1) }\end{array}$ & PVX_110810 & $\downarrow$ transcription $^{b}$ & & & 3 & ${ }^{26} \mathrm{E}-\mathrm{C}^{217} ;{ }^{198} \mathrm{~T}-\mathrm{D}^{524} ;{ }^{521} \mathrm{~T}-\mathrm{T}^{1000}$ \\
\hline $\begin{array}{l}\text { Reticulocyte-binding } \\
\text { protein 1a (PVRBP1a) }\end{array}$ & PVX_098585 & TP8 & & & 4 & $\begin{array}{l}{ }^{582} \mathrm{E}-\mathrm{E}^{1457} ;{ }^{1549} \mathrm{~F}-\mathrm{G}^{1758} ;{ }^{1880} \mathrm{~S}- \\
\mathrm{R}^{2229} ;{ }^{2} 2^{4} 5 \mathrm{~S}-\mathrm{E}^{2832}\end{array}$ \\
\hline $\begin{array}{l}\text { Rhoptry neck protein } 1 \\
\text { (PVRON1) }\end{array}$ & PVX_000945 & TP7 & Rhoptry neck protein & & 1 & ${ }^{25} \mathrm{~K}-\mathrm{R}^{772}$ \\
\hline $\begin{array}{l}\text { Rhoptry neck protein } 2 \\
\text { (PvRON2) }\end{array}$ & PVX_117880 & TP7 & & $x$ & 2 & ${ }^{735} \mathrm{G}-\mathrm{L}^{1560}$ and ${ }^{1554} \mathrm{~L}-\mathrm{V}^{2203}$ \\
\hline $\begin{array}{l}\text { Rhoptry neck protein } 5 \\
\text { (PVRON5) }\end{array}$ & PVX_089530 & TP7 & & $x$ & 1 & $\begin{array}{l}{ }^{23} \mathrm{~F}_{-W^{500}}(P \vee R O N 5 \mathrm{~A}) ;{ }^{50} \mathrm{~N}- \\
P^{1158}(\text { PvRON5C) }\end{array}$ \\
\hline $\begin{array}{l}\text { Rhoptry neck protein } 4 \\
\text { (PvRON4) }\end{array}$ & PVX_091434 & TP7 & & & 1 & ${ }^{25} \mathrm{~F}-\mathrm{P}^{756}$ \\
\hline $\begin{array}{l}\text { Rhoptry-associated } \\
\text { protein } 1 \text { (PVRAP1) }\end{array}$ & PVX_085930 & TP7 & Rhoptries & & 1 & ${ }^{2} \mathrm{~T}-\mathrm{Y}^{633}$ \\
\hline $\begin{array}{l}\text { Rhoptry-associated } \\
\text { protein } 2 \text { (PvRAP2) }\end{array}$ & PVX_097590 & TP7 & & $x$ & 1 & ${ }^{22} \mathrm{H}-\mathrm{H}^{382}$ \\
\hline $\begin{array}{l}\text { High molecular weight } \\
\text { rhoptry protein } 3 \\
\text { (PVRhopH3) }\end{array}$ & PVX_098712 & No data & & & 1 & ${ }^{21} \mathrm{Q}-\mathrm{F}^{599}$ \\
\hline $\begin{array}{l}\text { Rhoptry associated } \\
\text { membrane antigen } \\
\text { (PVRAMA) }\end{array}$ & PVX_087885 & TP7 & Rhoptry body protein & $x$ & 1 & ${ }^{21} \mathrm{~F}-\mathrm{G}^{710}$ \\
\hline \multicolumn{7}{|l|}{ Prey P. vivax protein } \\
\hline $\begin{array}{l}\text { 6-Cysteine protein } 12 \\
(P \vee 12)\end{array}$ & PVX_113775 & TP7 & Merozoite surface & $x$ & 1 & ${ }^{27} \mathrm{~T}-\mathrm{G}^{336}$ \\
\hline
\end{tabular}

and then incubated for $30 \mathrm{~min}$ at $37^{\circ} \mathrm{C}$, following previously described protocols [35, 37]. Microscope glass substrates were functionalized with aminosilane, as previously described $[41,42]$.
The 384-well-plates and functionalized substrate slides were loaded into an Ultra Marathon robotic microarray spotter (Arrayjet Inc.) configured for simultaneously printing 48 samples (including the plasmid from each 
selected antigen and control samples), producing $150 \mu \mathrm{m}$ features. cDNA-containing master mix samples $(500 \mathrm{pl}$ per sample containing approximately 3 ng plasmid DNA/ spot) were printed by non-contact inkjet printer (UltraMarathon, Arrayjet). The printer was set up to print sub-arrays in 8 rows $\times 6$ columns. Sixteen sub-arrays were printed per slide and each sub-array contained 29 cDNAs encoding $P$. vivax proteins and one cDNA encoding a $P$. falciparum protein. The printed arrays were then stored at room temperature in an airtight container with silica packets and protected from light. Several features were included in the array as negative controls, such as clean buffer, master mix without cDNA and master mix components independently (BSA or BS3 or anti-GST antibody).

\section{In situ protein expression using the NAPPA approach}

Once the array had been constructed and cDNA evaluated, proteins were expressed using two CFPS protocols: a rabbit reticulocyte lysate (RRL) (Promega) or 1-step human coupled in vitro translation (HCIVT) (Thermo Scientific) systems. The IVTT lysate master mix was prepared with $200 \mu \mathrm{L}$ reticulocyte lysate (Promega) containing $16 \mu \mathrm{L}$ TNT buffer, $8 \mu \mathrm{L}$ T7 polymerase, $4 \mu \mathrm{L}$-Met, $4 \mu \mathrm{L}$-Leu or -Cys, $8 \mu \mathrm{L}$ RNaseOut (Invitrogen Inc.) and $160 \mu \mathrm{L}$ DEPC water, following the manufacturer's instructions. The master mix for HCIVT was prepared by mixing $88 \mu \mathrm{L}$ HeLa lysate, $5.2 \mu \mathrm{L}$ accessory proteins, $10.8 \mu \mathrm{L}$ reaction mix, $1 \mu \mathrm{L}$ leupeptin and $1 \mu \mathrm{L}$ aprotinin (both at $1 \mu \mathrm{g} / \mathrm{mL}$ final concentration), as described by the manufacturer.

A HybriWell (Grace Biolabs Inc.) gasket was pressed onto the slides and each lysate master mix was individually added onto a slide through the gasket port. The HybriWell was gently massaged to spread the mix uniformly onto the array. Port seals were applied to both ports on the HybriWell to avoid evaporation. The arrays were incubated for $90 \mathrm{~min}$ at $30{ }^{\circ} \mathrm{C}$ and $30 \mathrm{~min}$ at $15{ }^{\circ} \mathrm{C}$ for protein expression and capture by the anti-GST polyclonal antibody. The HybriWell was then removed and the array washed three times with $\mathrm{PBS}$ for $5 \mathrm{~min}$ on a rocking platform.

\section{Analysing CDNA and protein display onto the arrays}

Prior to functional assays, some control experiments were performed to ensure the quality of printing and protein expression on the arrays (QC assays).

Printed arrays were washed with phosphate-buffered saline (PBS), $\mathrm{pH} 7.4$, for 15 min with gentle shaking, followed by a brief washing step with deionised water for $1 \mathrm{~min}$. The array surface was blocked with $20 \mathrm{~mL}$
Superblock PBS for $1 \mathrm{~h}$ at room temperature (RT) with gentle shaking followed by a $5 \mathrm{~min}$ wash with deionised water. The arrays were dried under a stream of filtered compressed air [40]. Blocked slides were incubated with $150 \mu \mathrm{L} /$ slide of 1:600 (v/v) diluted PicoGreen dye (Invitrogen Inc.) for staining the cDNA to evaluate DNA printing quality. The slides were scanned using a ProScanArray HT scanner (Perkin-Elmer) and the resulting images were analysed and quantified using GenePix Software version 6.0 (GenePix).

The slides were then incubated with Superblock PBS (Pierce) for $1 \mathrm{~h}$ at RT to ascertain whether protein expression had been universal throughout the whole array and then incubated with mouse anti-GST antibody (Cell Signaling Technologies Inc.) in Superblock PBS at 1:200 (v/v) dilution for $1 \mathrm{~h}$ at RT to evaluate protein expression throughout the whole array. After three 5-min washes with washing buffer (PBS $5 \%$ milk $+0.2 \%$ tween 20 ), the slides were incubated with HRP-linked anti-mouse IgG (Amersham) for $1 \mathrm{~h}$ at 1:200 dilution and washed again three times with PBS (5 min/wash). Signal was developed by incubating with $200 \mu \mathrm{L} /$ slide tyramide signal amplification reagent (Perkin-Elmer) for $10 \mathrm{~min}$ at RT. The slides were then rinsed with deionised water, dried using compressed air and scanned (array images were analysed as described above).

Query cDNA was co-expressed by supplementing the IVTT master mix (for RRL) with $1 \mu \mathrm{g}$ of cDNA encoding the $P v 12$ protein with a Halo tag to check in situ expressed $P$. vivax protein functionality (Table 1 and Additional file 3: Table S1); the interaction was then indirectly detected by incubation with anti-Halo antibody (Promega).

$P v 12$ interaction with the remaining proteins on the array was assessed by triplicate. Taking into account that each array contains 16 sub-arrays, each recombinant protein (all the 29 of them) is represented 16 times in each array.

\section{Processing microarray data and statistical analysis}

Computational processing of arrays began by acquiring the images, followed by analysing each spot [21]. Data was normalized (taking sub-array as analysis unit) by dividing the mean for the master mix (corrected for sub-array) by the difference in value of the spot's total fluorescence minus the average value for empty spot and/or master mix. If such value was $>1$ this meant the presence of DNA or protein in the spot. The mean of the previously normalized values was also obtained for analysing each clone's expression; if this was $>1$ it indicated protein presence [21,35,37]. 


\section{Results}

\section{Designing a Plasmodium vivax NAPPA}

Twenty genes encoding potential $P$. vivax vaccine candidates were selected based on several criteria (Table 1), such as the shared homology between $P$. vivax and $P$. falciparum sequences, functional evidence regarding target cell binding, antigenicity and/or immunogenicity, transcription during the last hours of the intraerythrocytic cycle (TP7-TP9) and evidence of expression in late schizonts and localization on parasite surface or apical organelles. Thirty-five PCR products were obtained from 20 selected $P$. vivax gene fragments, 29 of which were successfully cloned using Gateway technology (83\% efficiency) (Table 1 and Additional file 1: Fig. S1). This methodology used pDONR221 and two destination vectors (pANT7-cGST or PJFT7-nHalo) to transfer encoding sequences from the first plasmid to the second one (Fig. 1). pANT7-cGST contained a GST protein enabling nascent protein capture by a fixed polyclonal antibody against GST on the array, whilst query protein was cloned in pJFT7-nHalo (N-terminus Halo tag) and detected by monoclonal anti-Halo tag antibodies (Fig. 1).

This experimental approach has more advantages than traditional cloning methods because it does not require the use of restriction enzymes and site-specific recombination enables DNA fragments to be correctly cloned in

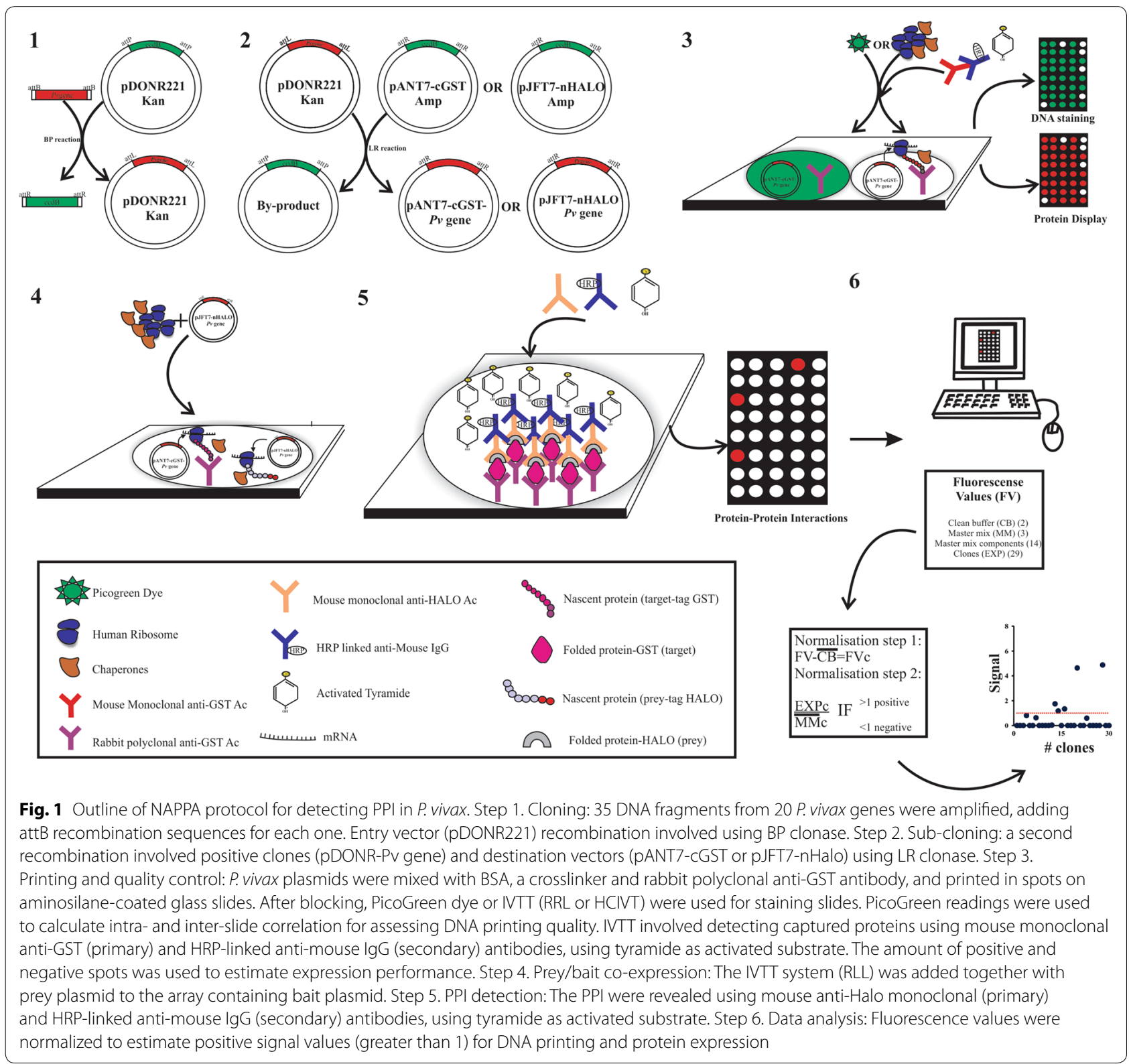


frame with GST or Halo tags, thereby simplifying cloning $[43,44]$. All the clones from this expression library were full-sequence validated and their sequences were analysed by BLAST to confirm their identity. A set of 10 clones (randomly selected from the expression library) were digested by BsrGI to verify insert presence and ascertain plasmid DNA quality (Fig. 2a). Expression library quality was validated and the clones were then ready for designing the NAPPA array.
Glycerol concentration and drop number were tested (data not shown) to homogenize and avoid aberrant effects as master mix component complexity (BSA, cDNA, cross-linkers, anti-tag antibody) could affect non-contact deposition and because viscosity plays a critical role. Optimal conditions were found to be $50 \%$ (v/v) glycerol and 5 drops per spot. The cDNA staining signal in these arrays was $>1$ in all the spots after normalization against control spots (master mix components without cDNA). This meant that all cDNAs in

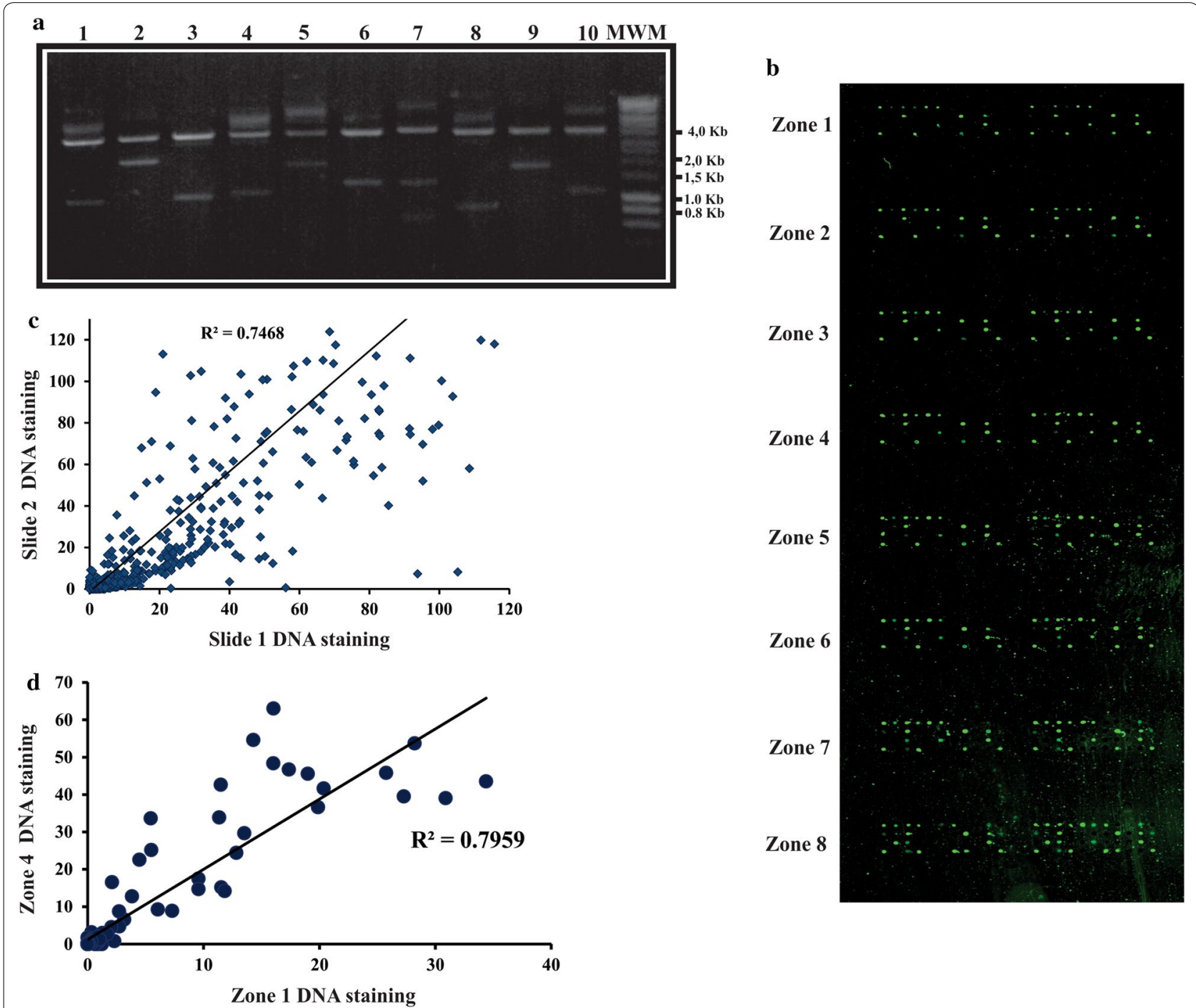

Fig. 2 Analysing printed DNA reproducibility. a Analysis of expression library quality by enzymatic digestion. The BsrGl enzyme was used for digestion; two DNA fragments were produced. The $4 \mathrm{kbp}$ band corresponds to the linearized vector, whilst the smaller fragment corresponds to the released insert. The presence of more than one band below $4 \mathrm{kbp}$ indicate that the insert contains restriction sites for BsrGl. MWM: molecular weight marker. At least two fragments were observed in all cases. b Scanning images showing the spots (i.e. DNA printed onto cell surface before expression). The Figure shows 16 sub-arrays (containing 29 clones and negative controls) for each array. Each region is represented by two sub-arrays. $\mathbf{c}$ Inter-slide reproducibility showing the relationship between normalized PicoGreen signals for clones printed in different arrays. $\mathbf{d}$ Intra-slide reproducibility showing the relationship between clones printed on different sub-arrays 
the expression library had been successfully deposited on the array by the non-contact strategy. For example, cDNA staining signal Duffy Binding Protein region-1 (DBP-RI) was detected in $94 \%$ of the spots.

The normalized signal obtained from printed cDNA was then evaluated across intra- and inter-arrays to evaluate robustness and reproducibility (Fig. 2), good intra-array $\left(R^{2}=0.80\right)$ and inter-array reproducibility $\left(R^{2}=0.75\right)$ being observed (Fig. 2). These results should guarantee consistent reproducibility levels for further studies with this $P$. vivax expression library.

\section{Self-assembling protein array displaying Plasmodium vivax proteins}

Spotted P. vivax cDNA was expressed in situ with RRL and protein presence was detected by anti-GST monoclonal antibody (as described in "Methods"). This led to signals being detected for all cDNAs in the P. vivax expression library in all printed cDNA (100\% efficiency) (Figs. 1, 3a, b, Additional file 2: Fig. S2). A second HeLa lysate-based in vitro expression system (HCIVT) was used with the same NAPPA P. vivax array. Nascent protein (C-terminal GST tag) was also detected by anti-GST monoclonal antibodies (as described in "Methods"). Figure 3b depicts the HCIVT system normalized signal; no expression was detected using this system although a signal was detected in $10 \%$ of the spots for the following 17 proteins (normalized signal $>1)$ : $\left(P f \mathrm{MSP} 1_{83}, P v 41, P v \mathrm{MSP} 10, P v \mathrm{MSP} 1_{42}\right.$, PvMSP4, PvMSP5, PvMSP8, PvRAP2, PvRBP1a-RIV, $P v$ RBP1a-RI, PvRBP1a-RII, PvRBP1a-RIII, PvRON1, $P \nu$ RON2-RII, $P v$ RON2-RIII, $P \nu$ RON4 and $P \nu$ RON5C).

\section{Plasmodium vivax in situ protein-protein interaction} studies

Recent protein-protein interaction screening has involved using Avidity-based extracellular interaction screening (AVEXIS) technology to characterize interaction between 34 P. vivax Mrz proteins (bait and preys) [45]. This intra-library AVEXIS was only able to identify three $P$. vivax protein-protein interactions in bait-prey orientation, one such being $P v 12$ interaction with $P v 41$ protein. $P v 12$ protein interaction was then tested with $P$. vivax proteins displayed on the array to evaluate whether NAPPA was working properly; $P \nu 12$ is a GPI-anchored 6-Cys protein expressed on parasite schizont surface and associated with DRM complexes [46], this being where the formation of several of the parasite's protein complexes involved in host cell interactions take place [47].

Pv12 was then cloned and sub-cloned (pDONR221 and pJFT7-nHalo) as described in "Methods" (Table 1 and Additional file 3: Table S1). Pv12 as query protein was co-IVTT expressed with a $P$. vivax cDNA library array for in situ protein interaction studies; interactions were detected by anti-Halo tag antibody (Fig. 1), showing that $P v 12$ interacted with five $P$. vivax proteins located on surface membrane and in rhoptry organelles, mainly with $P \nu \mathrm{RBP} 1 \mathrm{a}$ region IV and $P \nu 41$ proteins (Fig. 4).

\section{Discussion}

Most pathogen (i.e. Plasmodium) invasion is PPI-mediated, leading to stable or transient molecular complex formation [48]. Identifying and characterizing these types of interaction strongly suggests a functional relationship between participating proteins and enables understanding the biological mechanisms (replication, transcription,
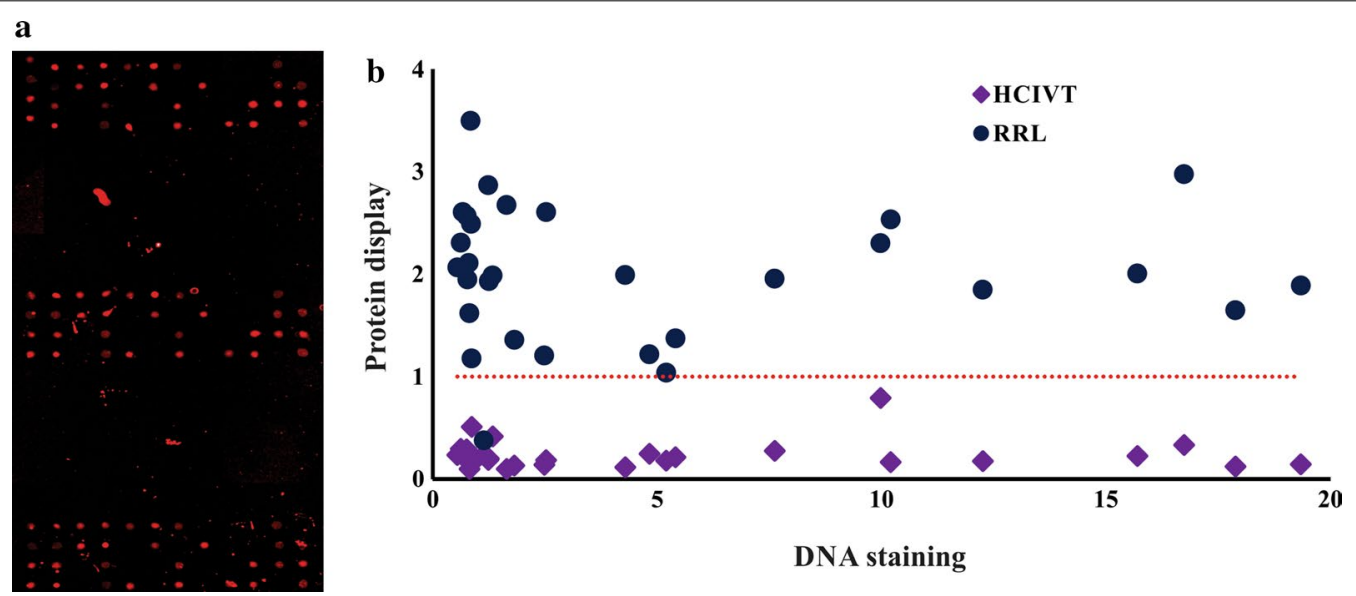

Fig. 3 Analysing Plasmodium vivax protein expression using RRL or HCIVT in NAPPA arrays and Western blot. a Scanning images showing the spots for three sub-arrays for proteins expressed with the RRL system after incubation with anti-GST. b Comparing P. vivax antigen expression with rabbit reticulocyte lysate (RRL) and 1-step human coupled IVT (HCIVT). The relationship between normalized cDNA signal and normalized protein signal for each expression system is shown. Values greater than 1 were considered positive 


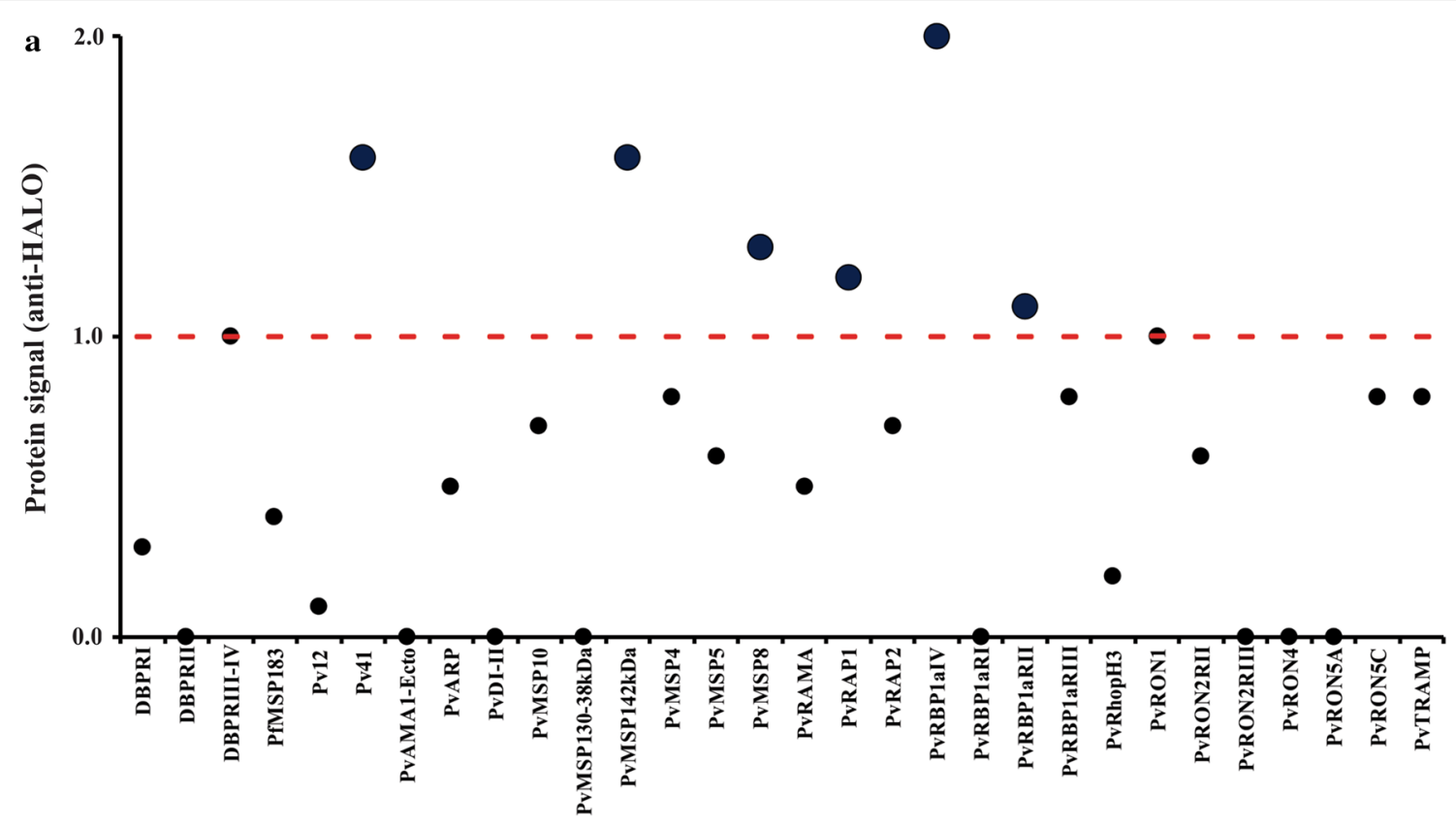

Protein names

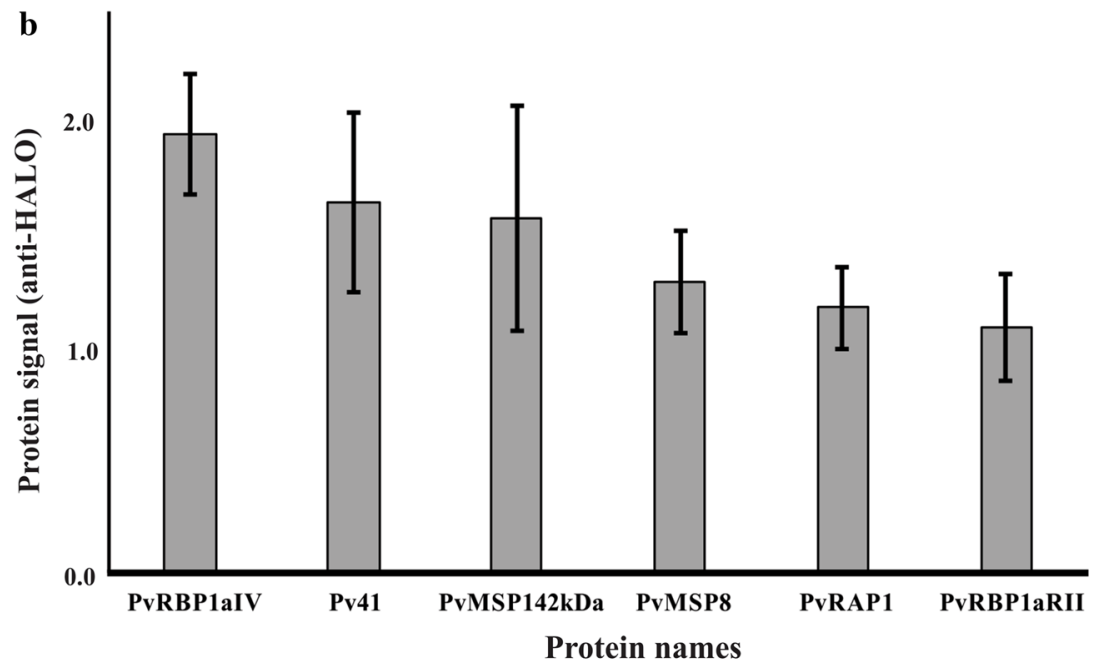

Fig. 4 NAPPA functional assessment of Plasmodium vivax proteins. a The $P v 12$ protein was used as query for evaluating its interaction with $29 P$. vivax protein fragments displayed on the array and one P. falciparum protein (PFMSP1 ${ }_{83 \mathrm{kDa} a}$ ). Query DNA encoding an N-terminal Halo tag was added to reticulocyte lysate for co-expression with bait proteins. The interaction signal was determined with anti-Halo antibodies. Normalized values are shown for 30 clones evaluated on the array. A median value $>1$ was considered positive interaction. b Median value \pm standard deviation of proteins interacting with Pv12

metabolism and invasion) used by microorganisms for invading and infecting target cells. Blocking PPI has been suggested as a target for action against pathogens by designing new drugs or small binding molecules targeting cell surface or the contact region between proteins $[49,50]$.
NAPPA is one of the chosen methodologies for characterizing PPIs. The first step in this study was thus the rational selection of content and query and evaluating whether a variety of such $P$. vivax proteins could be displayed by this format (Fig. 1). Twenty proteins were selected based on criteria described in the Results section (Table 1) $[15,51-55]$ and functional evidence of 
these antigens in $P$. vivax and other species (i.e., $P$. falciparum) during Mrz invasion of target cells [15].

Selected antigens (Table 1) were subdivided into three groups according to their subcellular location on Mrz surface proteins and proteins located in the micronemes and in the rhoptries. Mrz surface proteins are primarily exposed on Mrz plasma membrane during invasion and some of them are involved in weak, low-affinity interactions with receptors on RBC membrane for selecting a specific target cell $[3,56]$. Four proteins were selected from the Mrz surface (MSP) group (PvMSP-1, $-4,-8$ and -10); all of them are membrane-anchored via glycosylphosphatidylinositol (GPI) and expressed on $P$. vivax schizonts [57-59]. MSP1 is the major MSP and has been implicated in many $P$. falciparum receptor-ligand (glycophorin A, B and 3 and heparin) and protein-protein interactions (MSP6-MSP7-RhopH3-RAPs) [7, 8, 11]. It has been the object of significant antigenic and immunological studies highlighting its importance as $P$. falciparum and $P$. vivax vaccine antigen candidate $[60,61]$. The other surface antigen group selected here included the Plasmodium-specific 6-Cys family containing a cysteinerich domain, the 6-cysteine or s48/45 domain [62]. This Plasmodium-specific family's proteins are expressed in a stage-specific manner and perform important functions during life-cycle (gamete, Spz or Mrz) stages. P12 and P41 proteins have been characterized as bloodstage 6-Cys proteins in $P$. falciparum and $P$. vivax and have been seen to form a stable complex on the infective DRM-associated Mrz surface [45, 63].

Microneme and RON proteins are involved in highaffinity interactions initiating parasite entry to RBC. Native $P v \mathrm{RBP} 1 \mathrm{a}$ is colocalized on Mrz microneme with PvDBP [64]; whilst RBP proteins are responsible for the specificity of $P$. vivax Mrz binding to reticulocytes, $P v$ DBP is involved in $P$. vivax selectivity for invading Duffy antigen cells expressed on reticulocyte surface [65]; both proteins have been considered important vaccine candidates [60]. The AMA-1 protein has been implicated in macro-complex formation, together with RON2, -4 and -5 proteins for establishing the $\mathrm{TJ}$ necessary for parasite mobilization inside its target cell [66]. The content of the rhoptries involved in PV formation is then discharged onto a host/target cell for successful entry [67]. Many proteins have been seen to be involved in this last step during Mrz invasion, such as RhopH3, RAP1 and RAP2. P. falciparum RAP1, RAP2 and RAP3 form a low molecular weight complex in the bulb of the rhoptries, this being invasion-inhibitory monoclonal antibodies' target in vitro [68]. Other proteins such as $P v$ TRAMP, $P v$ RON1 and $P v \mathrm{ARP}$ have been recently identified and characterized in $P$. vivax schizonts and have been recognized by $P$. vivax-infected individuals' serum [69-71].
The array was designed to display cDNA encoding $P$. vivax proteins several times so as to have several replicates but mostly to avoid cross-contamination across features and highly homogeneous spot morphology. A non-contact printer was used to create these arrays which, apart from the requirements described above, had an advantage regarding the amount of cDNA per master mix (3 $\mu \mathrm{g})$ compared to $10-15 \mu \mathrm{g}$ cDNA/master mix previously reported in arrays constructed by microcontact printers [37].

One of the greatest challenges when working with protein microarray formats is being able to guarantee the proper folding and posttranslational modifications. The proteins produced and purified in heterologous systems, especially $E$. coli, may either lack modifications or display unnatural ones. The CFES, particularly the eukaryotic ones, offer an open, customizable and versatile system that contains the machinery for introducing the desired modifications such as acetylations, glycosylations, phosphorylations and signal peptide processing, amongst others [72-74]. It is worth highlighting that eukaryotic extracts also contain mammalian ribosomal machinery and the presence of chaperones, like hsp90, hsc70 and others, which may encourage folding [27]. Different studies in Plasmodium have shown that eukaryotic expression in live cells (i.e. HEK293 cells) or CFES (i.e. WGE and HeLa cells) are able to produce properly folded recombinant proteins. As an example, $39 P$. vivax antigens have been expressed in HEK293 cells, most of which were recognized by pooled plasma from 14 patients having acute vivax malaria, the seroreactivity decreased at least $20 \%$ when the recombinant proteins were heattreated, indicating that they contained conformationsensitive epitopes [45]. Another study has shown that $P$. vivax proteins from both merozoite and sporozoite forms expressed in WGE are better recognized by sera of $P$. vivax patients than the same proteins when produced in E. coli [30]. Moreover, when a $P$. vivax metalloprotease, encoded by the PvHSP28 gene, was expressed with a RRL system, it retains all its enzymatic activity [75]. The RRL system is one of the most used NAPPA expression systems, producing hundreds of proteins including various microorganisms' proteomes and more than 1000 human proteins $[29,36,76]$. The present study has shown the feasibility of producing $P$. vivax antigens from surface membrane, rhoptries and micronemes in array format with the RRL system (Fig. 3). Although previous studies in Plasmodium have shown that HeLa cell lysates were able to express four P. falciparum antigens with a varying degree of solubility, when the HCIVT system (based on HeLa cell lysates) was here used in array format, the expression of the $29 P$. vivax fragments was lower than that obtained using the RRL system (Fig. 3). However, 
further experiments are required to optimize HCIVTexpressed array performance regarding $P$. vivax; this could include increasing lysate concentration, expression time, temperature or adding protease inhibitors.

When $P$. vivax protein-protein interactions were measured it was found that $P v 12$ protein used as bait interacted with $P v 41$, as previously described using AVEXIS technology [45]. AVEXIS is based on measuring protein-protein interactions between bait (biotinylated and captured by streptavidin-coated wells) and prey proteins (enzymatically tagged and containing a pentamerization domain to increase interaction avidity) [77]. This technology has been used to ascertain Rh5 interaction with the Basigin receptor [78], Rh5 interaction with $P f 113$ protein [79] and recently for evaluating $P$. vivax protein-protein interactions [45]. These studies were only able to detect three interactions between 34 bait and prey proteins (i.e. very few interactions compared to those identified in $P$. falciparum) $[45,80]$. Although AVEXYS can increase avidity, prey pentamerization can cause steric hindrance affecting real detection of protein-protein interactions.

NAPPA detected interaction between $P v 12$ and other MSP (in addition to $P v 12-P v 41$ interaction), such as $P v \mathrm{MSP} 1_{42 \mathrm{kDa}}$ and $P v \mathrm{MSP} 8$ and proteins located in the apical organelles, such as $P \nu$ RAP1 and $P \nu$ RBP1a (Fig. 4), which confirms the ability of this technique for detecting binary interactions in $P$. vivax. Although six interactions with $P v 12$ were detected, this does not necessarily mean that all of them have an effective chance of occurring, due to time or spatial differences in the expression of such proteins so, methodologically, such interactions must be confirmed by using other techniques such as immunoprecipitation, pull down assays or isothermal titration calorimetry. On the other hand, it is not that strange detecting interactions amongst proteins coming from different sub-cellular localization in Plasmodium, as an example, it has been reported that the $P$. falciparum apical merozoite antigen-1 (PfAMA-1), originally localized in the micronemes, is able to interact with proteins expressed in rhoptry necks, leading to the tight junction formation that the parasite establishes with the target cell [66]. Moreover, it has been described that the P. falciparum P113 protein, anchored to the Surface membrane, specifically interacts with Rh5, expressed in the rhoptries [79]. Previous studies have described $P v 12$ forming part of DRMs [46], a platform where many Mrz invasionassociated proteins are organized into multi-protein complexes [47], thereby suggesting that $P v 12$ could be involved in forming a complex between parasite proteins. It is worth stressing that, in addition to NAPPA's advantages regarding expression, in situ co-expression of analyte and query and RT storage, it has higher sensitivity than other protein-protein interaction measurement techniques, mainly because the protein-protein complex is only found in the small microspot area, resulting in increased high local signal. Although few molecules can be captured in the microspot, high density molecules can be obtained in it [81].

\section{Conclusions}

NAPPA is a high-performance technique for evaluating interactions in $P$. vivax, offering a new and useful alternative for studying the biology of this difficult-to-culture parasite. It enables bait and query co-expression in situ, thereby enabling interactions to be analysed rapidly and reproducibly. NAPPA seems to be a flexible approach for identifying key PPI in full- or targeted-proteomes. This article has highlighted the NAPPA and RRL-based expression system for the successful and reproducible expression of $P$. vivax proteins which might be involved in $P$. vivax Mrz protein-protein interactions. The query protein $(P v 12)$ was able to interact with parasite surface membrane- and apical organelle-derived Mrz proteins. This technique will facilitate studying therapeutic targets and clarifying protein-protein interaction mechanisms.

\section{Additional files}

\section{Additional file 1: Fig. S1. A representative sample of $P$. vivax gene} amplicons.

Additional file 2: Fig. S2. Protein subarray map. The localization of each construct and control in each sub-array is shown. Each sub-array contains 48 spots in total and each array contains 16 sub-arrays. Controls include printing with just clean buffer, BS3, BSA+BS3, cDNA without master mix, polyclonal anti-Halo antibody, anti-GST monoclonal antibody or anti-Halo monoclonal antibody. A sub-array of protein expression using the RRL system is shown below. Anti-Halo antibodies were printed to capture the Pv12 protein on the array.

Additional file 3: Table S1. List of primers used, amplicon size, expressed products' molecular weight and destination vectors for the genes analysed.

\section{Authors' contributions}

GAP carried out the molecular biology assays, participated in NAPPA assays and wrote the initial manuscript. MGG and JCS carried out NAPPA assay. CS and $\mathrm{HC}$ processed and analysed NAPPA data. AM, MAP, JL and MF participated in coordinating and designing the assays. MAP evaluated and coordinated the molecular biology assays and revised the final manuscript. MF evaluated and coordinated the NAPPA assays and revised the final manuscript. All authors read and approved the final manuscript.

\section{Author details}

${ }^{1}$ Fundación Instituto de Inmunología de Colombia (FIDIC), Carrera 50 \# 26-20, Bogotá, Colombia. ${ }^{2}$ PhD Programme in Biomedical and Biological Sciences, Universidad del Rosario, Carrera 24 \# 63C-69, Bogotá, Colombia. ${ }^{3}$ Proteomics Unit, Cancer Research Centre (IBMCC/CSIC/USAL/IBSAL), 37007 Salamanca, Spain. ${ }^{4}$ Department of Medicine and General Cytometry Service-Nucleus, Cancer Research Centre (IBMCC/CSIC/USAL/IBSAL), 37007 Salamanca, Spain. ${ }^{5}$ Universidad de Ciencias Aplicadas y Ambientales (U.D.C.A.), Calle 222 \# 55-37, Bogotá, Colombia. ${ }^{6}$ School of Medicine and Health Sciences, Universidad del Rosario, Carrera 24 \# 63C-69, Bogotá, Colombia. ${ }^{7}$ Unidad de Investigación Enfermedades Infecciosas y Tropicales (e-INTRO), Instituto de Investigación 
Biomédica de Salamanca-Centro de Investigación de Enfermedades Tropicales de la Universidad de Salamanca (IBSAL-CIETUS), Facultad de Farmacia, Universidad de Salamanca, Campus Universitario Miguel de Unamuno s/n, 37007 Salamanca, Spain. ${ }^{8}$ Virginia G. Piper Center for Personalized Diagnostics, Biodesign Institute, Arizona State University, Tempe, AZ, USA.

\section{Acknowledgements}

We would like to thank Jason Garry for translating this manuscript.

\section{Competing interests}

The authors declare that they have no competing interests.

\section{Availability of data and materials}

All data generated or analysed during this study is included within this article.

\section{Consent for publication}

Not applicable.

\section{Ethics approval and consent to participate}

Not required.

\section{Funding}

This research was financed by the Colombian Departamento Administrativo de Ciencia, Tecnología e Innovación (COLCIENCIAS) through contract RC\# 0309-2013 and the Spanish Institute of Health Carlos III (ISCIII) through Grant FIS PI 14/01538 \& FIS PI 17/01930. We would also like to acknowledge contributions from the European Regional Development Fund (ERDF), the Junta Castilla-León (BIO/SA07/15) and Fundación Solórzano (FS-23-2015). The Proteomics Unit forms part of ProteoRed, PRB3-ISCIII, supported by Grant PT17/0019/0023, PE I+D+I 2017-2012, funded by ISCIII and ERDF. The Proteomics Unit belongs to ProteoRed, PRB3-ISCIII, supported by Grant PT17/0019/0023. The work was carried out during Arévalo-Pinzón's PhD internship financed by COLCIENCIAS within the framework of the "Convocatoria Nacional para Estudios de Doctorado en Colombia (call for candidates no. 567)".

\section{Publisher's Note}

Springer Nature remains neutral with regard to jurisdictional claims in published maps and institutional affiliations.

Received: 21 December 2017 Accepted: 10 July 2018

Published online: 17 July 2018

\section{References}

1. Mueller I, Galinski MR, Baird JK, Carlton JM, Kochar DK, Alonso PL, et al. Key gaps in the knowledge of Plasmodium vivax, a neglected human malaria parasite. Lancet Infect Dis. 2009;9:555-66.

2. Noulin F, Borlon C, Van Den Abbeele J, D'Alessandro U, Erhart A. 19122012: a century of research on Plasmodium vivax in vitro culture. Trends Parasitol. 2013;29:286-94.

3. Weiss GE, Gilson PR, Taechalertpaisarn T, Tham WH, de Jong NW, Harvey $\mathrm{KL}$, et al. Revealing the sequence and resulting cellular morphology of receptor-ligand interactions during Plasmodium falciparum invasion of erythrocytes. PLoS Pathog. 2015;11:e1004670.

4. Lopaticki S, Maier AG, Thompson J, Wilson DW, Tham WH, Triglia T, et al. Reticulocyte and erythrocyte binding-like proteins function cooperatively in invasion of human erythrocytes by malaria parasites. Infect Immun. 2011;79:1107-17.

5. Stubbs J, Simpson KM, Triglia T, Plouffe D, Tonkin CJ, Duraisingh MT, et al. Molecular mechanism for switching of $P$. falciparum invasion pathways into human erythrocytes. Science. 2005;309:1384-7.

6. Lin CS, Uboldi AD, Marapana D, Czabotar PE, Epp C, Bujard H, et al. The merozoite surface protein 1 complex is a platform for binding to human erythrocytes by Plasmodium falciparum. J Biol Chem. 2014;289:25655-69.

7. Kauth CW, Woehlbier U, Kern M, Mekonnen Z, Lutz R, Mucke N, et al. Interactions between merozoite surface proteins 1, 6, and 7 of the malaria parasite Plasmodium falciparum. J Biol Chem. 2006;281:31517-27.
8. Ranjan R, Chugh M, Kumar S, Singh S, Kanodia S, Hossain MJ, et al. Proteome analysis reveals a large merozoite surface protein-1 associated complex on the Plasmodium falciparum merozoite surface. J Proteome Res. 2011;10:680-91.

9. Wanaguru M, Crosnier C, Johnson S, Rayner JC, Wright GJ. Biochemical analysis of the Plasmodium falciparum erythrocyte-binding antigen-175 (EBA175)-glycophorin-A interaction: implications for vaccine design. J Biol Chem. 2013;288:32106-17.

10. Batchelor JD, Malpede BM, Omattage NS, DeKoster GT, Henzler-Wildman KA, Tolia NH. Red blood cell invasion by Plasmodium vivax: structural basis for DBP engagement of DARC. PLoS Pathog. 2014;10:e1003869.

11. Li X, Chen H, Oo TH, Daly TM, Bergman LW, Liu SC, Chishti AH, et al. A co-ligand complex anchors Plasmodium falciparum merozoites to the erythrocyte invasion receptor band 3. J Biol Chem. 2004;279:5765-71.

12. Lin CS, Uboldi AD, Epp C, Bujard H, Tsuboi T, Czabotar PE, et al. Multiple Plasmodium falciparum merozoite surface protein 1 complexes mediate merozoite binding to human erythrocytes. J Biol Chem. 2016;291:7703-15.

13. Baldwin MR, Li X, Hanada T, Liu SC, Chishti AH. Merozoite surface protein 1 recognition of host glycophorin A mediates malaria parasite invasion of red blood cells. Blood. 2015;125:2704-11.

14. Vogel G. The forgotten malaria. Science. 2013;342:684-7.

15. Patarroyo MA, Calderon D, Moreno-Perez DA. Vaccines against Plasmodium vivax: a research challenge. Expert Rev Vaccines. 2012;11:1249-60.

16. Pizzi E, Frontali C. Low-complexity regions in Plasmodium falciparum proteins. Genome Res. 2001;11:218-29.

17. Mehlin C, Boni E, Buckner FS, Engel L, Feist T, Gelb MH, et al. Heterologous expression of proteins from Plasmodium falciparum: results from 1000 genes. Mol Biochem Parasitol. 1000;2006(148):144-60.

18. Gardner MJ, Hall N, Fung E, White O, Berriman M, Hyman RW, et al. Genome sequence of the human malaria parasite Plasmodium falciparum. Nature. 2002;419:498-511.

19. Hillebrecht JR, Chong S. A comparative study of protein synthesis in in vitro systems: from the prokaryotic reconstituted to the eukaryotic extract-based. BMC Biotechnol. 2008:8:58.

20. Hino M, Kataoka M, Kajimoto K, Yamamoto T, Kido J, Shinohara Y, et al. Efficiency of cell-free protein synthesis based on a crude cell extract from Escherichia coli, wheat germ, and rabbit reticulocytes. J Biotechnol. 2008;133:183-9.

21. Diez P, Dasilva N, Gonzalez-Gonzalez M, Matarraz S, Casado-Vela J, Orfao A, et al. Data analysis strategies for protein microarrays. Microarrays (Basel). 2012;1:64-83.

22. Manzano-Roman R, Dasilva N, Diez P, Diaz-Martin V, Perez-Sanchez R, Orfao A, et al. Protein arrays as tool for studies at the host-pathogen interface. J Proteomics. 2013;94:387-400.

23. Tsuboi T, Takeo S, Iriko H, Jin L, Tsuchimochi M, Matsuda S, et al. Wheat germ cell-free system-based production of malaria proteins for discovery of novel vaccine candidates. Infect Immun. 2008;76:1702-8.

24. Doolan DL, Mu Y, Unal B, Sundaresh S, Hirst S, Valdez C, et al. Profiling humoral immune responses to $P$. falciparum infection with protein microarrays. Proteomics. 2008;8:4680-94.

25. Mu J, Awadalla P, Duan J, McGee KM, Keebler J, Seydel K, et al. Genomewide variation and identification of vaccine targets in the Plasmodium falciparum genome. Nat Genet. 2007;39:126-30.

26. Yadavalli R, Sam-Yellowe T. HeLa Based cell free expression systems for expression of Plasmodium rhoptry proteins. J Vis Exp. 2015:e52772.

27. Zemella A, Thoring L, Hoffmeister C, Kubick S. Cell-free protein synthesis: pros and cons of prokaryotic and eukaryotic systems. ChemBioChem. 2015;16:2420-31.

28. Chen JH, Jung JW, Wang Y, Ha KS, Lu F, Lim CS, et al. Immunoproteomics profiling of blood stage Plasmodium vivax infection by high-throughput screening assays. J Proteome Res. 2010;9:6479-89.

29. Ramachandran N, Raphael JV, Hainsworth E, Demirkan G, Fuentes MG, Rolfs A, et al. Next-generation high-density self-assembling functional protein arrays. Nat Methods. 2008;5:535-8.

30. Rui E, Fernandez-Becerra C, Takeo S, Sanz S, Lacerda MV, Tsuboi T, et al. Plasmodium vivax: comparison of immunogenicity among proteins expressed in the cell-free systems of Escherichia coli and wheat germ by suspension array assays. Malar J. 2011;10:192.

31. Dent AE, Nakajima R, Liang L, Baum E, Moormann AM, Sumba PO, et al. Plasmodium falciparum protein microarray antibody profiles correlate 
with protection from symptomatic malaria in Kenya. J Infect Dis. 2015;212:1429-38.

32. Molina DM, Finney OC, Arevalo-Herrera M, Herrera S, Felgner PL, Gardner $\mathrm{MJ}$, et al. Plasmodium vivax pre-erythrocytic-stage antigen discovery: exploiting naturally acquired humoral responses. Am J Trop Med Hyg. 2012;87:460-9.

33. Carlson ED, Gan R, Hodgman CE, Jewett MC. Cell-free protein synthesis: applications come of age. Biotechnol Adv. 2012;30:1185-94.

34. Montor WR, Huang J, Hu Y, Hainsworth E, Lynch S, Kronish JW, et al. Genome-wide study of Pseudomonas aeruginosa outer membrane protein immunogenicity using self-assembling protein microarrays. Infect Immun. 2009;7:4877-86.

35. Henjes F, Lourido L, Ruiz-Romero C, Fernandez-Tajes J, Schwenk JM, Gonzalez-Gonzalez M, et al. Analysis of autoantibody profiles in osteoarthritis using comprehensive protein array concepts. J Proteome Res. 2014;13:5218-29.

36. Yu X, Decker KB, Barker K, Neunuebel MR, Saul J, Graves M, et al. Hostpathogen interaction profiling using self-assembling human protein arrays. J Proteome Res. 2015;14:1920-36.

37. Manzano-Roman R, Diaz-Martin V, Gonzalez-Gonzalez M, Matarraz S, Alvarez-Prado AF, LaBaer J, et al. Self-assembled protein arrays from an Ornithodoros moubata salivary gland expression library. J Proteome Res. 2012;11:5972-82.

38. Yap A, Azevedo MF, Gilson PR, Weiss GE, O'Neill MT, Wilson DW, et al. Conditional expression of apical membrane antigen 1 in Plasmodium falciparum shows it is required for erythrocyte invasion by merozoites. Cell Microbiol. 2014;16:642-56.

39. Williams AR, Douglas AD, Miura K, Illingworth JJ, Choudhary P, Murungi LM, et al. Enhancing blockade of Plasmodium falciparum erythrocyte invasion: assessing combinations of antibodies against PfRH5 and other merozoite antigens. PLoS Pathog. 2012;8:e1002991.

40. Smallwood SE, Rahman MM, Werden SJ, Martino MF, McFadden G. Production of Myxoma virus gateway entry and expression libraries and validation of viral protein expression. Curr Protoc Microbiol. 2011. https:// doi.org/10.1002/9780471729259.mc14a02s21.

41. Link AJ, Labaer J. Construction of nucleic acid programmable protein arrays (NAPPA) 1: coating glass slides with amino silane. CSH Protoc. 2008. https://doi.org/10.1101/pdb.prot5056.

42. Gonzalez-Gonzalez M, Bartolome R, Jara-Acevedo R, Casado-Vela J, Dasilva N, Matarraz S, et al. Evaluation of homo- and hetero-functionally activated glass surfaces for optimized antibody arrays. Anal Biochem. 2014:50:37-45

43. Katzen F. Gateway((R)) recombinational cloning: a biological operating system. Expert Opin Drug Discov. 2007;2:571-89.

44. Hunt I. From gene to protein: a review of new and enabling technologies for multi-parallel protein expression. Protein Expr Purif. 2005;40:1-22.

45. Hostetler JB, Sharma S, Bartholdson SJ, Wright GJ, Fairhurst RM, Rayner JC. A library of Plasmodium vivax recombinant merozoite proteins reveals new vaccine candidates and protein-protein interactions. PLoS Negl Trop Dis. 2015;9:e0004264.

46. Moreno-Perez DA, Areiza-Rojas R, Florez-Buitrago X, Silva Y, Patarroyo ME, Patarroyo MA. The GPI-anchored 6-Cys protein Pv12 is present in detergent-resistant microdomains of Plasmodium vivax blood stage schizonts. Protist. 2013;164:37-48.

47. Sanders PR, Cantin GT, Greenbaum DC, Gilson PR, Nebl T, Moritz RL, et al. Identification of protein complexes in detergent-resistant membranes of Plasmodium falciparum schizonts. Mol Biochem Parasitol. 2007;154:148-57.

48. Paing MM, Tolia NH. Multimeric assembly of host-pathogen adhesion complexes involved in apicomplexan invasion. PLoS Pathog. 2014;10:e1004120.

49. Wells JA, McClendon CL. Reaching for high-hanging fruit in drug discovery at protein-protein interfaces. Nature. 2007;450:1001-9.

50. Srinivasan P, Yasgar A, Luci DK, Beatty WL, Hu X, Andersen J, et al. Disrupting malaria parasite AMA1-RON2 interaction with a small molecule prevents erythrocyte invasion. Nat Commun. 2013;4:2261.

51. Moreno-Perez DA, Degano R, Ibarrola N, Muro A, Patarroyo MA. Determining the Plasmodium vivax VCG-1 strain blood stage proteome. J Proteomics. 2014;113C:268-80.
52. Lu F, Li J, Wang B, Cheng Y, Kong DH, Cui L, et al. Profiling the humoral immune responses to Plasmodium vivax infection and identification of candidate immunogenic rhoptry-associated membrane antigen (RAMA). J Proteomics. 2014;102:66-82.

53. Acharya P, Pallavi R, Chandran S, Dandavate V, Sayeed SK, Rochani A, et al. Clinical proteomics of the neglected human malarial parasite Plasmodium vivax. PLoS ONE. 2011;6:e26623.

54. Acharya P, Pallavi R, Chandran S, Chakravarti H, Middha S, Acharya J, et al. A glimpse into the clinical proteome of human malaria parasites Plasmodium falciparum and Plasmodium vivax. Proteomics Clin Appl. 2009:3:1314-25.

55. Roobsoong W, Roytrakul S, Sattabongkot J, Li J, Udomsangpetch R, Cui L. Determination of the Plasmodium vivax schizont stage proteome. J Proteomics. 2011;74:1701-10

56. Beeson JG, Drew DR, Boyle MJ, Feng G, Fowkes FJ, Richards JS. Merozoite surface proteins in red blood cell invasion, immunity and vaccines against malaria. FEMS Microbiol Rev. 2016;40:343-72.

57. Perez-Leal O, Sierra AY, Barrero CA, Moncada C, Martinez P, Cortes J, et al. Identifying and characterising the Plasmodium falciparum merozoite surface protein 10 Plasmodium vivax homologue. Biochem Biophys Res Commun. 2005;331:1178-84.

58. Perez-Leal O, Sierra AY, Barrero CA, Moncada C, Martinez P, Cortes J, et al. Plasmodium vivax merozoite surface protein 8 cloning, expression, and characterisation. Biochem Biophys Res Commun. 2004;324:1393-9.

59. Black CG, Barnwell JW, Huber CS, Galinski MR, Coppel RL. The Plasmodium vivax homologues of merozoite surface proteins 4 and 5 from Plasmodium falciparum are expressed at different locations in the merozoite. Mol Biochem Parasitol. 2002;120:215-24.

60. Lopez C, Yepes-Perez Y, Hincapie-Escobar N, Diaz-Arevalo D, Patarroyo MA. What is known about the immune response induced by Plasmodium vivax malaria vaccine candidates? Front Immunol. 2017:8:126.

61. Singh S, Miura K, Zhou H, Muratova O, Keegan B, Miles A, et al. Immunity to recombinant Plasmodium falciparum merozoite surface protein 1 (MSP1): protection in Aotus nancymai monkeys strongly correlates with anti-MSP1 antibody titer and in vitro parasite-inhibitory activity. Infect Immun. 2006;74:4573-80.

62. Arredondo SA, Cai M, Takayama Y, MacDonald NJ, Anderson DE, Aravind $L$, et al. Structure of the Plasmodium 6-cysteine s48/45 domain. Proc Natl Acad Sci USA. 2012;109:6692-7.

63. Taechalertpaisarn T, Crosnier C, Bartholdson SJ, Hodder AN, Thompson J, Bustamante LY, et al. Biochemical and functional analysis of two Plasmodium falciparum blood-stage 6-cys proteins: P12 and P41. PLOS ONE. 2012;7:e41937

64. Han JH, Lee SK, Wang B, Muh F, Nyunt MH, Na S, et al. Identification of a reticulocyte-specific binding domain of Plasmodium vivax reticulocytebinding protein 1 that is homologous to the PfRh4 erythrocyte-binding domain. Sci Rep. 2016;6:26993.

65. Prajapati SK, Singh OP. Insights into the invasion biology of Plasmodium vivax. Front Cell Infect Microbiol. 2013;3:8.

66. Vulliez-Le Normand B, Tonkin ML, Lamarque MH, Langer S, Hoos S, Roques $\mathrm{M}$, et al. Structural and functional insights into the malaria parasite moving junction complex. PLoS Pathog. 2012;8:e1002755.

67. Zuccala ES, Gout AM, Dekiwadia C, Marapana DS, Angrisano F, Turnbull $L$, et al. Subcompartmentalisation of proteins in the rhoptries correlates with ordered events of erythrocyte invasion by the blood stage malaria parasite. PLoS ONE. 2012;7:e46160.

68. Ridley RG, Takacs B, Etlinger H, Scaife JG. A rhoptry antigen of Plasmodium falciparum is protective in Saimiri monkeys. Parasitology. 1990;101(Pt 2):187-92.

69. Moreno-Perez DA, Saldarriaga A, Patarroyo MA. Characterizing PvARP, a novel Plasmodium vivax antigen. Malar J. 2013;12:165.

70. Moreno-Perez DA, Montenegro M, Patarroyo ME, Patarroyo MA. Identification, characterization and antigenicity of the Plasmodium vivax rhoptry neck protein 1 (PvRON1). Malar J. 2011;10:314.

71. Mongui A, Angel DI, Moreno-Perez DA, Villarreal-Gonzalez S, Almonacid $H$, Vanegas $M$, et al. Identification and characterization of the Plasmodium vivax thrombospondin-related apical merozoite protein. Malar J. 2010:9:283. 
72. Gibbs PE, Zouzias DC, Freedberg IM. Differential post-translational modification of human type I keratins synthesized in a rabbit reticulocyte cell-free system. Biochim Biophys Acta. 1985;824:247-55.

73. Safer B, Jagus R. Control of elF-2 phosphatase activity in rabbit reticulocyte lysate. Proc Natl Acad Sci USA. 1979;76:1094-8.

74. Shields D, Blobel G. Efficient cleavage and segregation of nascent presecretory proteins in a reticulocyte lysate supplemented with microsomal membranes. J Biol Chem. 1978;253:3753-6.

75. Fakruddin JM, Biswas S, Sharma YD. Metalloprotease activity in a small heat shock protein of the human malaria parasite Plasmodium vivax. Infect Immun. 2000;68:1202-6.

76. Yu X, LaBaer J. High-throughput identification of proteins with AMPylation using self-assembled human protein (NAPPA) microarrays. Nat Protoc. 2015;10:756-67.

77. Bartholdson SJ, Crosnier C, Bustamante LY, Rayner JC, Wright GJ. Identifying novel Plasmodium falciparum erythrocyte invasion receptors using systematic extracellular protein interaction screens. Cell Microbiol. 2013;15:1304-12
78. Crosnier C, Bustamante LY, Bartholdson SJ, Bei AK, Theron M, Uchikawa $M$, et al. Basigin is a receptor essential for erythrocyte invasion by Plasmodium falciparum. Nature. 2011;480:534-7.

79. Galaway F, Drought LG, Fala M, Cross N, Kemp AC, Rayner JC, et al. P113 is a merozoite surface protein that binds the $\mathrm{N}$ terminus of Plasmodium falciparum RH5. Nat Commun. 2017:8:14333.

80. LaCount DJ, Vignali M, Chettier R, Phansalkar A, Bell R, Hesselberth JR, et al. A protein interaction network of the malaria parasite Plasmodium falciparum. Nature. 2005;438:103-7.

81. Templin MF, Stoll D, Schrenk M, Traub PC, Vohringer CF, Joos TO. Protein microarray technology. Trends Biotechnol. 2002;20:160-6.

82. Bozdech Z, Mok S, Hu G, Imwong M, Jaidee A, Russell B, et al. The transcriptome of Plasmodium vivax reveals divergence and diversity of transcriptional regulation in malaria parasites. Proc Natl Acad Sci USA. 2008;105:16290-5.
Ready to submit your research? Choose BMC and benefit from:

- fast, convenient online submission

- thorough peer review by experienced researchers in your field

- rapid publication on acceptance

- support for research data, including large and complex data types

- gold Open Access which fosters wider collaboration and increased citations

- maximum visibility for your research: over 100M website views per year

At BMC, research is always in progress.

Learn more biomedcentral.com/submissions 